\title{
How Much are Aware of the Effects of Smartphone use in Daily Activities?
}

\author{
Vaccaro $\mathbf{M}^{1,2 *}$ \\ ${ }^{1}$ IESCUM, European Institute for the Study of Human Behavior, Italy \\ ${ }^{2}$ Associazione un mondo in $3 \mathrm{~d}$, Italy
}

*Corresponding author: Marianna Vaccaro, Ph.D, IESCUM, European Institute for the Study of Human Behavior, Italy, Email: marianna.vaccaro@yahoo.it

\section{Review Article \\ Volume 4 Issue 2}

Received Date: April 03, 2020

Published Date: April 24, 2020

DOI: $10.23880 /$ eoij-16000233

\section{Abstract}

The aim of the article is to highlight the consequences that the presence of the smartphone has induced in people's lives in daily activities such as driving, sleeping and studying. Its pervasiveness also affects mental health by increasing depressive symptoms, chronic stress and anxiety. Physically, it leads to gain weight, since it negatively affects appetite and food intake control. The literature shows that it is not the tool itself that is harmful but the frequency of use that the individual makes of it in everyday life. Born as a tool capable of speeding up communication and reducing distances at a geographical level, it presents itself today as an element that hinders face-to-face communication and causes a change in relationships. Recent studies identify among the problematic behaviors resulting from the easiness of use and transport of the smartphone, the phantom vibration syndrome, the fear of remaining without a smartphone - Nomophobia, FOMO, fear of not being continuously informed and of losing what happens online, Phubbing, specific behavior that consists in neglecting the person with whom you are engaged in any social situation, to compulsively watch, control and touch the smartphone. According to this situation, it is important to intervene and sensitize the population to obtain a reduction in the frequency of use of the smartphone, leaving the man free to choose, compared to the man that he would like to be, how much time to actually dedicate in the use of the smartphone and as for the reality that surrounds him.

Keywords: Smartphone; Phubbing; Nomofobia; Fomo; Behavior

\section{Introduction}

Technology, involving any kind of people in spite of factors like gender, age or socioeconomic status, provides an opportunity to expand social communication and make it more immediate [1-3]. Nowadays smartphones are a fundamental and essential instrument for the life of millions of people. Smartphones are used both by adults and the elderly and not only for business purposes [4-9]. In the 2020 the use of digital devices in Italy has increased by more than $10 \%$.

The $79 \%$ of the Italian population is online (50 million people), with 35 million active users on social media. The data show very clearly how smartphones, instead of computers, are becoming the favourite instrument to visit the web. The advantage of smartphones is the possibility to install any sort of apps that make it possible a better management of e-mails and/or agenda; to book trains or flights and to buy metro or bus tickets; to spend time in recreational activities, to take photos, to send and receive images, to observe and produce videos, to listen to music, store documents, to read and share contents and information, to access social networks or instant chats [10-13]. According to the surveys conducted by We Are Social (2020) in collaboration with Hootsuite (a social media management platform that collects data related to the use of social channels, mobile devices and all the other digital tools and that monitors data of the global and 
the individual markets), in Italy the most used applications are: WhatsApp (83\%), Facebook (80\%), YouTube (88\%) and
Instagram (64\%) (Figure 1).

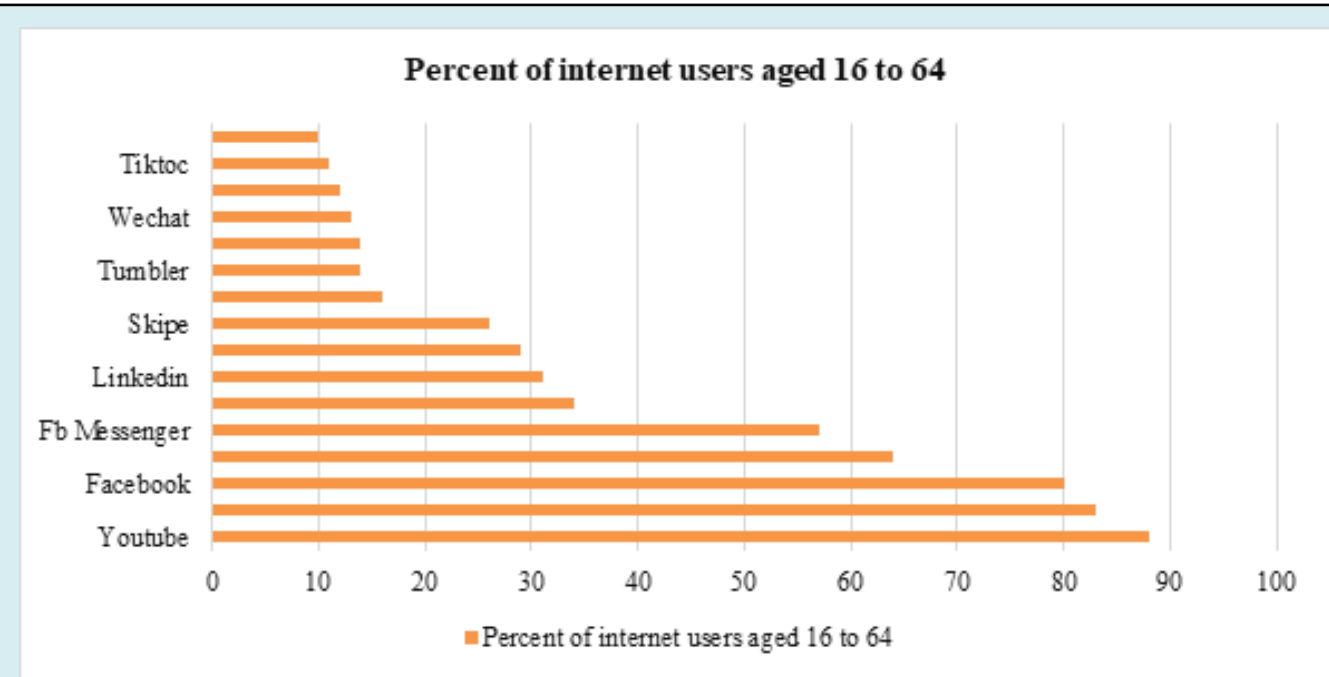

Figure 1: The histogram shows the data on the overall use of social networks and online platforms of the Italian population on the basis of the data reported by the We Are Social site, 2020.

The spread of digital devices has inevitably produced a cultural revolution over the last few years, with important changes in people's habits, concerning their relation with the context and their means of communication. The side effects caused by the presence of the smartphone in people's lives do not depend on the device itself but on the frequency of use [4,14-16].

Risks related to the frequency of use have been observed in in different contexts of daily life:

- Sleeping: Sleeping is a biological mechanism related to mood regulation [17]. Therefore, the reduction or interruption of sleep to use the smartphone can cause loss of energy, concentration problems and daytime sleepiness [18]. There is a correlation between smartphone addiction and alteration of sleep duration [19]. The use of devices and of the Internet postpones bedtime [20] and induces indirect negative effects on users, as it entails sleep deprivation [21] and it has an impact on the constructive phase of sleep, reducing the duration of the REM phase [22,23]. The REM phase occurs in the last half of a full night of sleep and, if compromised, it can cause negative consequences on learning skills [24]. The blue light present on the screen and the electromagnetic waves emitted can suppress the secretion of melatonin and can delay the onset of sleep [25-27]. This can simultaneously cause an alteration of cerebral blood flow and electrical activity of the brain [28]. In addition, Thomée, Härenstam and Hagberg [17] reported that the prolonged use of smartphone, especially before falling asleep, can cause physical problems, such as muscle, wrist or neck pain, blurred vision, aggressiveness, attention deficit, depression and headaches, which can in turn negatively affect sleep quality, as confirmed by numerous other studies [20,21,24,29-38].

- Studying: The presence and frequency of use of the mobile device at school reduces attention, concentration, the ability to understand and memorize notions [13,3941]. Out of 349 students from six different departments of a US college, the entire sample reported having a smartphone and $99.1 \%$ of them confirmed to use it in class to receive or send messages while waiting for the beginning of the lesson or even during the lesson. Additional activities revealed in the study are related to other functions of device (the clock, the calculator, the Internet, etc.). $51.6 \%$ of students aimed to put the device in vibrate mode, $44.4 \%$ in silent mode, $1.7 \%$ in ringer mode and only $2.3 \%$ to turn it off. Regarding the reasons that induce students to behave in this way, $13 \%$ confirmed to use the device to stay in touch with the world, another $13 \%$ to play games, but most of the interviewees $(60 \%)$ indicated that the reason is that they get bored. Only 14\% of respondents reported using the smartphone for emergencies [42]. Many researches reveal the negative impact [43-51] of the use of devices on students involved in study, school and extracurricular activities, that is accentuated by the fact that they are involved in multitasking activities [52]. This condition entails an overload of information and it reduces 
attention and listening skills.

- Driving: The use of devices to call, to send text or voice messages is related to a decrease of level of attention and to an increase of response time in the presence of a stimulus, such as vehicle stopping at the sight of a pedestrian crossing the road [53] or keeping the vehicle in lane without invading the other. The same can be said for the use of the hands-free mode while driving [54], but also for pedestrians who use their smartphone to call or send text messages during a walk or while crossing the street [55]. Many researches have highlighted that the use of the device to send / receive calls or messages causes a decrease in awareness of the surrounding context, producing a greater number of risk behaviours, with a greater number of accidents, injuries and deaths [56]. The alarming element is that these behaviours are considered normal in everyday life [57], despite the awareness that distractions or improper driving are the cause of about $25 \%$ of driving crashes. In this regard, the analysis conducted by Seiler [58] on the social factors that have an influence on the use of the smartphone while driving has suggested an important reflection. Intuitively, observing people who drive in a dangerous way should discourage you from making the same mistake: instead, traveling with people who use their smartphone to text or phone while driving without any negative consequences helps to create a favourable attitude to this behaviour in the passenger. When a dangerous behaviour becomes part of daily routine, it is considered normal and acceptable. Many studies identified three categories of distractions in which drivers may incur: visual, manual and cognitive bias. Safe driving depends on these three functions and if one of the three fails, the performance worsens and you are slower in stopping, have difficulties following or changing the direction of driving and are more likely to run into crashes [59]. Among the causes of distraction emerge the involvement in a double task, like driving and use the hands-free option of the device. Divided attention negatively affects driving performance [60].

- Being Multitasking: Multitasking is the common denominator of activities compromised by the use of the smartphone, while there is a tendency to believe that this method can facilitate contact with people, coordinate daily activities and lead to an increase in productivity [6]. Being multitasking creates the illusion of saving time but, on the contrary, recent research has shown that the consequences of shifting attention to different tasks are negative, because it requires a cost in terms of time, energy, commitment and effectiveness during information processing $[46,61]$. The belief of being able to carry out multiple activities simultaneously without cognitive costs seems to have no foundation $[3,62]$. In fact, in most of the cases, dividing the attention between multiple tasks makes the cognitive process slower and more complex, in addition to decrease the quality of processing and the quantity of information learned [63]. Having good results with multimedia multitasking is possible when there is no time limit for processing information [64] and when it is possible choose whether to focus attention on a specific task [6]. Misuse of mobile technology has a negative impact on productivity, both in terms of quantity and quality of work: stopped in working activity occurs in average every 15 minutes, and it takes time to regain attention at each time [65]. For example, while performing an activity, a 3-second distraction, which is the time needed to take and silence the smartphone, is enough to interrupt the attention process: the result is that after the interruption the number of errors doubles. The longer the outage, the higher the error rate [66]. Paradoxically, technology, built with the intention of saving time and improving productivity, on the opposite can cause a waste of time and money, with harmful consequences on one's activities, at work and at home [67].

\section{Smartphone and Mental Health}

Excessive use of the device can have negative consequences and in severe cases can cause depression, chronic stress, anxiety [68,69], it can increase suicidal thinking [70] and it is related with weight gain, as the use of devices adversely affects appetite and control on food intake [71]. We can talk of tecnostress that is the stress connected to an overload of information and communication [69] or of psychological regression [72]. Lonely people, who have relational difficulties, can entertain various activities, undertake online games, take photos and videos, search for news, text with friends and read a book with their smartphone, sitting comfortably at home, thus reinforcing avoidance with each real contact. These behaviours allow them to close themselves in a sort of protective shell [73]. Recent studies have identified the "phantom vibration syndrome" [74] the fear of running without a smartphone and have called "nomophobia" [75-77], and FOMO, the fear of not being continuously informed and therefore of losing what happens online [34,78].

- Nomophobia: It is defined as the uncontrolled fear of being suddenly disconnected from the mobile network or of having the smartphone out of battery without an electrical outlet available nearby [76]. A survey conducted in 2008 by the British post office on a sample of over 2,000 people found that $53 \%$ of respondents felt anxious when they did not have their smartphone with them. People who suffer from nomophobia have a disproportionate fear of being left without network coverage, to the point of experiencing physical 
symptoms similar to panic attack: shortness of breath, dizziness, tremors, sweating, rapid heartbeat, chest pain and nausea. The strategies put in place to avoid anxious states include having always credit, bringing a charger or external battery everywhere, providing an alternative mobile number to relatives and friends to be able to be always contacted. Since photos, contacts, messages contained in the mobile phone are fundamental elements of their life, if it gets lost, these subjects feel like they lost a highly important part of their existence, with a consequent sense of distress. A study conducted by King, Valença and Nardi indicates that nomophobia is a dysfunctional behaviour that should be considered more as a pathological addiction than an anxiety disorder. British researchers have indeed found that a therapeutic approach aimed at reducing anxiety is not effective in treating this behaviour.

- Fear of Missin Out - FOMO: It is the fear of being cut off from what happens on the network and it is manifested by the fear of losing a lot of information and of remaining excluded from possible interesting activities. FOMO is not a pathology recognized at clinical level. It includes the lack of appreciation of experiences outside the network and the persistency of obsessive thoughts about the activities one is missing [79]. It involves agitation and impatience because one would always want to be at the centre of the action [80]. As consequence, who suffers of this pathology compulsively checks his smartphone to be updated moment by moment on what happens to friends, relatives, acquaintances and even strangers. A need that, if not satisfied, can cause a real abstinence crisis [81]. In this case, people compulsively access their devices for fear of losing a "social update" or for selfsatisfaction and this behaviour is implemented in all circumstances, regardless of where they are and what they are doing. A study conducted by Thornton and colleagues, listed several specific situations in which it occurs: during downtime at school and at work, daily commutes on public transport, while queuing in offices or driving, while one is engaged in recreational activities at home such as watching television or playing with kids, or outside during walking or shopping. Some of the statements reported by the interviewees are worthy of interest, such as: "I would feel uncomfortable if I didn't have my smartphone with me" or "I would prefer to lose the wallet rather than the smartphone".

\section{Changes in Interaction: The phubbing}

The analysis of the effects of the smartphone on interpersonal relationships is extremely complex. The original intent of mobile phones was to allow and facilitate the sharing of verbal or written messages between people in the various areas of the world. Then, phones' functions were increased, regardless of personal technical-IT skills and everyone has had the opportunity to develop bi-or multi-lateral interactions, to obtain greater visibility, to move in a virtual world without spatial restrictions, with a reduced physical and mental effort and cost. The sphere of social interactions has been strengthened and expanded to the point that everyone has become free to reach the others anywhere, without the need to be in the same place. A more fluid culture of social interactions was therefore born, based on instantaneous interactions and on immediate and not-predefined agreements, which made it possible to create diversified relationships, groups, organizations and institutions. It also facilitated highly informal and spontaneous cooperation $[49,82,83]$.

Over the years this new condition has also proved to be a cost to people and the entire community. The new generations today can "cancel" themselves in their smartphones: for example, instead of being simply bored if involved an uninteresting conversation, they can access video games, social networks or send text messages, starting a virtual conversation with a more stimulating interlocutor [84].

Smartphone's "mediated communication" is preferred to face-to-face interaction [85]. Making a phone call or having an appointment or meeting has been replaced by sending e-mails and text messages. People prefer to update their status rather than inviting a friend to have a coffee. This does not mean that human beings are less social, it is the way of communication that is changed [86].

You have greater confidence in a stranger, because you are less afraid of the judgment and this allows for greater freedom of expression in the content of the messages; we prefer to interact with interlocutors who avoid confrontation, who are quick and concise in a response rather than oriented to sharing and outsourcing different points of view [85].

Goffman's observations $[87,88]$ on people's behaviour in public places provided important pieces of information on the new rules of social interaction. Communicating through smartphones does not simultaneously involve the five senses, as in face-to-face communication. When we sit in front of a table with another person who talks to us, if his smartphone starts ringing announcing a call or message, it becomes an element of distraction and we feel excluded. In a study conducted by Pearson and Hussain [89], the 7\% of the interviewees said that they feel abandoned or isolated when their partner use their smartphone during a conversation. In doing so, motivation to confrontation fails and empathy decreases. Empathy is the ability to understand and trust the others and allows us to get in touch and understand the thoughts and moods of the others: if it fails, also the quality 
of the human relationship suffers.

These data are confirmed in a study conducted by Przybylski and Weinstein [81]. The authors observed 74 strangers in a restaurant. They were asked to converse in pairs, for ten minutes, on a specific topic (for example, the most interesting event of the last month). The evaluation of the participants regarding the quality of the relationship (for example, "level of appreciation of the partner") and of the feelings associated with the partner (eg closeness, trust and empathy) were lower when a smartphone was present on the table. These differences were even more evident when the topic chosen in the discussion was significant for the person and related to his experience (the most important event for you in the last year) rather than casual (considerations on plans for the next holiday). The presence of a smartphone on the table was a source of distraction in the couples and it made face-to-face communication more difficult.

This behaviour is frequent in social situations, such as an aperitif or a dinner, where people often deprive themselves of the company of those present to participate, both mentally and physically, in virtual relationships [90,], focusing on other issues and shifting the focus out of the experience they are currently experiencing, without being aware of it [91].

The two studies presented in the article "Can you connect with me now? How the presence of mobile communication technology influences face-to-face conversation quality" [81], have shown how the presence of a smartphone on the table has negative effects on feelings of closeness, mutual contact and on the quality of the conversation. What we see today in pubs and restaurants is precisely the situation described by Krasnova, Abramova, Notter and Baumann
[92]: people already have their smartphone in hand when they enter in a restaurant. They sit at the table and place on it their smartphone. While consulting menu, if they don't know a dish, their smartphone helps them to find out it. Then, when the food arrives, with one hand they grab it and with the other hand they touch the screen of the smartphone, to check or send text or voice messages and keep their eyes down. They are able to consume their dish in thirty minutes interacting only with their smartphone. Once finished they pay and go out with their device in hand.

In line with these studies, "phone snubbing" is defined [93] as a specific behaviour of neglecting or "snubbing" the person with whom you are experiencing a social situation (like drinking a coffee or an aperitif in a pub) to compulsively watch, control or touch the smartphone, even if the context and social conventions would push to create interactions or provide attention to the other people present. The term was created in occasion of the Macquarie Dictionary campaign in 2012, to indicate the disrespectful behaviour of students who use their smartphone while the professor speaks in class. This trend is increasingly widespread in our society, to the level that it is no longer recognized as anomalous. This behaviour seems to have become habitual and automatic. As consequence, it has been coined the term "Phubbing" to define the interpersonal problem created by the high frequency of use of smartphones during a conversation with friends, relatives or acquaintances: focusing on one's device becomes a barrier to meaningful communication and therefore it can cause conflicts, with a consequent decrease of satisfaction towards the relationship a person is involved in and with an impairment of individual well-being [94,95] (Figure 2).

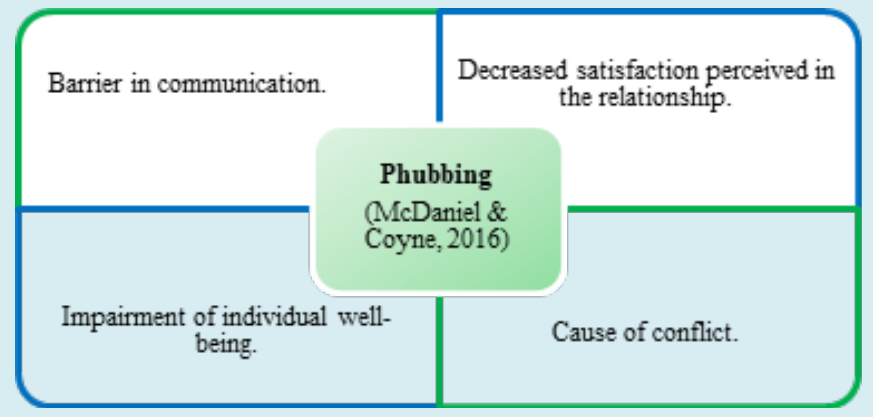

Figure 2: The table illustrates the consequences induced by the Phubbing phenomenon.

According to Roberts and David [95], the most important predictor of Phubbing is the dependence on social media, on the mobile device and on the Internet. In their study conducted on 145 adults, the phenomenon of Phubbing emerged as responsible for the loss of marital satisfaction and it often generated couple's conflicts and depression in the partner. Researchers believe that this phenomenon may even be a factor contributing to the failure of relationships and to a change in the shape of friendships, because of an increase of rude and inattentive behaviour. The subject is 
part of a vicious circle. Ignored by the interlocutor intent on looking at his smartphone, he focuses, as reaction, his attention on his device and on social media too, supporting the raise of mutual Phubbing attitude, as if it were "normal" behaviour. The Phubbing drives people to unreal worlds (the online universe) and it distances them from reality.

We train our brains to think by going from one link to another, from one social to another, we no longer stop to ponder or reflect, to raise our eyes and direct them to whom we are looking at. We are creatures that have become predominantly reactive. The use of the smartphone puts us in front of a reality where doing must be faster than thinking.

Keeping your smartphone next to your plate while eating is now a habit, an automatic behaviour that is repeated in a given context or situation and that is the product of three phases: signalling, gratification and routine [96]. For example, when you sit at a table with friends, if the conversation is not very interesting and it bores you, the mere sight of your device (emotional and physical stimulus) leads you to take it in hand (routine) and feeling pleasure in the activities it mediates (gratification). The brain thus associates the device with the elimination of boredom and this means that every time we feel bored or have a free minute, we will be inclined to take the smartphone in hand. Habits, although many times can be useful in daily life because they allow us not to overload our brain, in other cases such as the one described, are harmful. As Nassin Nicholas Taleb [97] reports, what differentiates technology from slavery is the fact that slaves are aware that they are not free. Habits cannot be cancelled but it can be useful to modify them, make small changes in the contexts in which the interaction between organism and environment takes place, changing the stimuli that trigger habitual behaviour and that allow you to make an action decision in advance when you is in specific and challenging situations.

According to this situation, it is important to intervene and raise awareness of the population by making them aware of the side effects that the high frequency of use of the smartphone entails in daily life. This could push man to change his habits and choose how long, the man he would like to be, would actually devote to the use of the smartphone and how much to the reality that surrounds him.

\section{References}

1. Katz JE, Aspden P (1997) A nation of strangers? Communications of the ACM 40(12): 81-86.

2. Aoki K, Downes EJ (2003) An analysis of young people's use of and attitudes toward cell phones. Telematics and Informatics 20(4): 349-364.
3. Turkle S (2011) Alone together: Why we expect more from technology and less from each other. Basic Books, New York.

4. Bianchi A, Phillips JG (2005) Psychological predictors of problem mobile phone use. Cyberpsychology \& Behavior 8(1): 39-51.

5. Takao M, Takahashi S, Kitamura M (2009) Addictive Personality and Problematic Mobile Phone Use. Cyberpsychology \& Behavior 12(5): 501-507.

6. Smith A (2012) The best (and worst) of mobile connectivity. Pew Internet \& American Life Project.

7. Park N, Lee H (2012) Social implications of smartphone use: Korean college students' smartphone use and psychological well-being. Cyberpsychology, Behavior and Social Networking 15(9): 491-497.

8. Lundquist AR, Lefebvre EJ, Garramone SJ (2014) Smartphones: fulfilling the need for immediacy in everyday life, but at what cost. International Journal of Humanities and Social Science 4(2): 80-89.

9. Kim Y, Wang Y, Oh J (2016) Digital media use and social engagement: How social media and smartphone use influence social activities of college students. Cyberpsychology, Behavior, and Social Networking 19(4): 264-269.

10. Rainie L, Lenhart A, Fox S, Spooner T, Horrigan J (2000) Tracking on-line life. Pew Research Center.

11. Rainie L, Keeter S (2006) Americans and their cell phones. Pew Research Center.

12. Wei R (2008) Motivations for using the mobile phone for mass communications and entertainment. Telematics and Informatics 25(1): 36-46.

13. Duggan M, Rainie L (2013) Cell phone activities. Pew Research Center's Internet \& American Life Project, Washington, DC.

14. Palen L, Salzman M, Youngs E (2001) Discovery and integration of mobile communications in everyday life. Personal and ubiquitous computing 5(2): 109-122.

15. Monk A, Carroll J, Parker S, Blythe M (2004) Why are mobile phones annoying?. Behaviour \& Information Technology 23(1): 33-41.

16. Paragas F (2005) Being mobile with the mobile: Cellular telephony and renegotiations of public transport as public sphere. In Mobile Communications, Springer, London, pp: 113-129. 
17. Thomée S, Härenstam A, Hagberg M (2011) Mobile phone use and stress, sleep disturbances, and symptoms of depression among young adults-a prospective cohort study. BMC Public Health 11(1): 66.

18. Adams SK, Kisler TS (2013) Sleep quality as a mediator between technology-related sleep quality, depression, and anxiety. Cyberpsychology, Behavior and Social Networking 16(1): 25-30.

19. Canan F, Yildirim O, Sinani G, Ozturk O, Ustunel TY, et al. (2013) Internet addiction and sleep disturbance symptoms among Turkish high school students. Sleep and Biological Rhythms 11(3): 210-213.

20. Lemola S, Perkinson-Gloor N, Brand S, Dewald-Kaufmann JF, Grob A (2014) Adolescents' Electronic Media Use at Night, Sleep Disturbance, and Depressive Symptoms in the Smartphone Age. Journal of Youth and Adolescence 44(2): 405-418.

21. An J, Sun Y, Wan Y, Chen J, Wang X, et al. (2014) Associations between problematic Internet use and adolescents' physical and psychological symptoms: Possible role of sleep quality. Journal of Addiction Medicine 8(4): 282-287.

22. Higuchi S, Motohashi Y, Liu Y, Maeda A (2005) Effects of playing a computer game using a bright display on presleep physiological variables, sleep latency, slow wave sleep and REM sleep. Journal of Sleep Research 14(3): 267-273.

23. Dworak M, Schierl T, Bruns T, Strüder HK (2007) Impact of singular excessive computer game and television exposure on sleep patterns and memory performance of school-aged children. Pediatrics 120(5): 978-985.

24. Brown FC, Buboltz Jr WC, Soper B (2002) Relationship of sleep hygiene awareness, sleep hygiene practices, and sleep quality in university students. Behavioral medicine 28(1): 33-38.

25. Higuchi S, Motohashi Y, Liu Y, Ahara M, Kaneko Y (2003) Effects of VDT tasks with a bright display at night on melatonin, core temperature, heart rate, and sleepiness. Journal of Applied Physiology 94(5): 1773-1776.

26. Huber R, Treyer V, Borbely AA, Schuderer J, Gottselig JM, et al. (2002) Electromagnetic fields, such as those from mobile phones, alter regional cerebral blood flow and sleep and waking EEG. Journal of Sleep Research 11(4): 289-295.

27. Loughran SP, Wood AW, Barton JM, Croft RJ, Thompson B, et al. (2005) The effect of electromagnetic fields emitted by mobile phones on human sleep. Neuroreport 16(17): 1973-1976.

28. Wood AW, Loughran SP, Stough C (2006) Does evening exposure to mobile phone radiation affect subsequent melatonin production?. International Journal of Radiation Biology 82(2): 69-76.

29. Ozguner F, Altinbas A, Ozaydin M, Dogan A, Vural H, et al. (2005) Mobile phone-induced myocardial oxidative stress: protection by a novel antioxidant agent caffeic acid phenethyl ester. Toxicology and Industrial Health 21(7-8): 223-230.

30. Kuss DJ, Griffiths MD (2011a) Excessive online social networking: Can adolescents become addicted to Facebook? Education and Health 29(4): 68-71.

31. White AG, Buboltz W, Igou F (2011) Mobile phone use and sleep quality and length in college students. International Journal of Humanities and Social Science 1(18): 51-58.

32. Cajochen C, Frey S, Anders D, Späti J, Bues M, et al. (2011) Evening exposure to a light-emitting diodes (LED)backlit computer screen affects circadian physiology and cognitive performance. Journal of Applied Physiology 110(5): 1432-1438.

33. Munezawa T, Kaneita Y, Osaki Y, Kanda H, Minowa M, et al. (2011) The association between use of mobile phones after lights out and sleep disturbances among Japanese adolescents: a nationwide cross-sectional survey. Sleep 34(8): 1013-1020.

34. Kwon M, Kim DJ, Cho H, Yang S (2013) The Smartphone Addiction Scale: Development and Validation of a Short Version for Adolescents. PloS One 8(12): e83558.

35. Kwon M, Lee JY, Won WY, Park JW, Min JA (2013) Development and validation of a smartphone addiction scale (SAS). PloS One 8(2): e56936.

36. Lee YK, Chang CT, Lin Y, Cheng ZH (2014) The dark side of smartphone usage: Psychological traits, compulsive behavior and technostress. Computers in Human Behavior 31: 373-383.

37. Lepp A (2014) Exploring the relationship between cell phone use and leisure: an empirical analysis and implications for management. Managing Leisure 19(6): 381-389.

38. Lanaj K, Johnson RE, Barnes CM (2014) Beginning the workday yet already depleted? Consequences of late-night smartphone use and sleep. Organizational Behavior and Human Decision Processes 124(1): 11-23. 
39. Shelton JT, Elliott EM, Eaves SD, Exner AL (2009) The distracting effects of a ringing cell phone: An investigation of the laboratory and the classroom setting. Journal of environmental psychology 29(4): 513-521.

40. End CM, Worthman S, Mathews MB, Wetterau K (2009) Costly cell phones: The impact of cell phone rings on academic performance. Teaching of Psychology 37(1): 55-57.

41. Duggan M, Smith A (2013) Social media update 2013. Pew Research Internet Project.

42. Ugur NG, Koc T (2015) Time for digital detox: Misuse of mobile technology and phubbing. Procedia-Social and Behavioral Sciences 195: 1022-1031.

43. Lepp A, Barkley JE, Karpinski AC (2014) The relationship between cell phone use, academic performance, anxiety, and satisfaction with Life in college students. Computers in Human Behavior 31(1): 343-350.

44. Froese AD, Carpenter CN, Inman DA, Schooley JR, Barnes $\mathrm{RB}$, et al. (2012) Effects of classroom cell phone use on expected and actual learning. College Student Journal 46(2): 323-332.

45. Smith TS, Isaak MI, Senette CG, Abadie BG (2011) Effects of cell-phone and text-message distractions on true and false recognition. Cyberpsychology, Behavior, and Social Networking 14(6): 351-358.

46. Rosen LD, Carrier LM, Cheever NA (2013) Facebook and texting made me do it: Media-induced task-switching while studying. Computers in Human Behavior 29(3): 948-958.

47. Kibona L, Mgaya G (2015) Smartphones' effects on academic performance of higher learning students. Journal of Multidisciplinary Engineering Science and Technology 2(4): 777-784.

48. Harman BA, Sato T (2011) Cell phone use and grade point average among undergraduate university students. College Student Journal 45(3): 544-550.

49. Walsh JL, Fielder RL, Carey KB, Carey MP (2013) Female College students' media use and academic outcomes: Results from a longitudinal cohort study. Emerging Adulthood 1(3): 219-232.

50. Sánchez-Martínez M, Otero A (2009) Factors associated with cell phone use in adolescents in the community of Madrid (Spain). Cyberpsychology \& Behavior 12(2): 131-137.

51. Junco R, Cotton SR (2012) No A 4 U: The relationship between multitasking and academic performance. Computers \& Education 59(2): 505-514.

52. Elder A (2013) College Students' Cell Phone Use, Beliefs, and Effects on their Learning. College Student Journal 47(4): 585-592.

53. Drews FA, Yazdani H, Godfrey CN, Cooper JM, Strayer DL (2009) Text messaging during simulated driving. Human factors 51(5): 762-770.

54. Pennay D (2006) Community attitudes to road safety. Community attitudes survey wave 18, 2005 (No. CR 227), Australian Transport Safety Bureau, Canberra.

55. Yager C (2013) An evaluation of the effectiveness of voiceto-text programs at reducing incidences of distracted driving. Southwest Region University Transportation Center (US).

56. Nasar JL, Troyer D (2013) Pedestrian injuries due to mobile phone use in public places. Accident Analysis \& Prevention 57: 91-95.

57. Walsh SP, White KM, Young RM (2009) The phone connection: A qualitative exploration of how belongingness and social identification relate to mobile phone use amongst Australian youth. Journal of Community \& Applied Social Psychology 19(3): 225-240.

58. Seiler SJ (2015) Hand on the Wheel, Mind on the Mobile: An Analysis of Social Factors Contributing to Texting While Driving. Cyberpsychology, Behavior, and Social Networking 18(2): 72-78.

59. Sherin KM, Lowe AL, Harvey BJ, Leiva DF, Malik A, et al. (2014) Preventing texting while driving: A statement of the american college of preventive medicine. American Journal of Preventive Medicine 47(5): 681-688.

60. Trick LM, Enns JT, Mills J, Vavrik J (2004) Paying attention behind the wheel: A framework for studying the role of attention in driving. Theoretical Issues in Ergonomic Science 5(5): 385-424.

61. Frank B, Martin B, Marci CD, Rule R, Williams EH (2013) A (Biometric) Day in the Life. A Cross-Generational Comparison of Media Platforms.

62. Rosen C (2008) The myth of multitasking. The New Atlantis 20: 105-110.

63. Paoletti G (2010) Social software e multitasking: un virus o una risorsa?. Form@ re-Open Journal per la formazione in rete 10(66): 29-35.

64. Bowman LL, Levine LE, Waite BM, Gendron M (2010) 
Can students really multitask? An experimental study of instnt messaging while reading. Computers \& Education 54(4): 927-931.

65. Thornton B, Faires A, Robbins M, Rollins E (2014) The mere presence of a cell phone may be distracting: Implications for attention and task performance. Social Psychology 45(6): 479-488.

66. Altmann EM, Trafton JG, Hambrick DZ (2014) Momentary interruptions can derail the train of thought. Journal of Experimental Psychology: General 143(1): 215-226.

67. Crenshaw D (2008) The myth of multitasking: How "doing it all" gets nothing done. John Wiley \& Sons.

68. Demirci K, Akgönül M, Akpinar A (2015) Relationship of smartphone use severity with sleep quality, depression, and anxiety in university students. Journal of behavioral addictions 4(2): 85-92.

69. Samaha M, Hawi NS (2016) Relationships among smartphone addiction, stress, academic performance, and satisfaction with life. Computers in Human Behavior 57: 321-325.

70. Katsumata Y, Matsumoto T, Kitani M, Takeshima T (2008) Electronic media use and suicidal ideation in Japanese adolescents. Psychiatry and clinical neurosciences 62(6): 744-746.

71. Fujiwara T, Nakata R (2016) Smartphone usage during meals is a potential risk for weight gain in post-adolescent female students. Integr Food Nutr Metab 3(5): 424-426.

72. Geser H (2004) Towards a sociological theory of the mobile phone. E-Merging media: communication and the media economy of the future, pp: 235-260.

73. Bian M, Leung L (2014) Linking Loneliness, Shyness, Smartphone Addiction Symptoms, and Patterns of Smartphone use to Social Capital. Social Science Computer Review 33(1): 61-79.

74. Rothberg MB, Arora A, Hermann J, Kleppel R, St Marie $P$, et al. (2010) Phantom vibration syndrome among medical staff: a cross sectional survey. Bmj 341: c6914.

75. King AL, Valença AM, Nardi AE (2010) Nomophobia: the mobile phone in panic disorder with agoraphobia: reducing phobias or worsening of dependence? Cognitive Behavior Neurology 23(1): 52-54.

76. Hong FY, Chiu SI, Huang DH (2012) A model of the relationship between psychological characteristics, mobile phone addiction and use of mobile phones by Taiwanese university female students. Computers in
Human Behavior 28(6): 2152-2159.

77. King ALS, Valença AM, Silva ACO, Baczynski T, Carvalho MR, et al. (2013) Nomophobia: Dependency on virtual environments or social phobia?. Computers in Human Behavior 29(1): 140-144.

78. Przybylski AK, Weinstein N (2013) Can you connect with me now? How the presence of mobile communication technology influences face-to-face conversation quality. Journal of Social and Personal Relationships 30(3): 237-246.

79. Kozak A (2009) Wild Chickens and Petty Tyrants: 108 Metaphors for Mindfulness? Wisdom Pubns.

80. Turkle S (2012) Insieme ma soli. Perché ci aspettiamo sempre più dalla tecnologia e sempre meno dagli altri. Edizioni Codice, Milano.

81. Przybylski AK, Murayama K, DeHaan CR, Gladwell V (2013) Motivational, emotional, and behavioral correlates of fear of missing out. Computers in Human Behavior 29(4): 1841-1848.

82. Geser H (2006) Are girls (even) more addicted? Some gender patterns of cell phone usage. Sociology in Switzerland: Sociology of the Mobile Phone.

83. Puryear C, Reysen S (2013) A Preliminary Examination of Cell Phone Use and Helping Behavior. Psychological Reports 113(3): 1001-1003.

84. Bindley K (2011) When children text all day, what happens to their social skills? Huffington Post.

85. Keller M (2013) Social media and interpersonal communication. Social Work Today 73(3): 10.

86. Wagner LA (2015) When Your Smartphone Is Too Smart for Your Own Good: How Social Media Alters Human Relationships. Journal of Individual Psychology 71(2): 114-121.

87. Goffman E (1963) Behavior in Public Places: Notes on the Social Organization of Gatherings. Free Press, New York.

88. Goffman E (1971) Relations in Public: Microstudies of the Public Order. Harper \& Row, New York.

89. Pearson C, Hussain Z (2015) Smartphone Use, Addiction, Narcissism, and Personality. International Journal of Cyber Behavior, Psychology and Learning 5(1): 17-32.

90. Plant S (2000) The effects of mobile telephones on social and individual life. Report commissioned by Motorola. 
91. Srivastava L (2005) Mobile phones and the evolution of social behaviour. Behaviour \& Information Technology 24(2): 111-129.

92. Krasnova H, Abramova O, Notter I, Baumann A (2016) Why phubbing is toxic for your relationship: Understanding the role of smartphone jealousy among "Generation Y" users. Research Papers 109.

93. Karadağ E, Tosuntaş ŞB, Erzen E, Duru P, Bostan N, et al. (2015) Determinants of phubbing, which is the sum of many virtual addictions: A structural equa-tion model. Journal of Behavioral Addictions 4(2): 60-74.

94. McDaniel BT, Coyne SM (2016) Technoference: The interference of technology in couple relationships and implications for women's personal and relational wellbeing. Psychology of Popular Media Culture 5(1): 85-98.

95. Roberts JA, David ME (2016) My life has become a major distraction from my cell phone: Partner phubbing and relationship satisfaction among romantic partners. Computers in Human Behavior 54: 134-141.

96. Wood W, Neal DT (2007) A new look at habits and the habit-goal interface. Psychological Review 114(4): 843863.

97. Taleb NN (2010) Il letto di Procuste. Aforismi per tutti i giorni. Il Saggiatore. 